diminishes, while the subject thinks he is writing faster.

The pressure curves obtained from children differ from all the adult types. A flat-topped curve had been considered until recently the characteristic child's curve (Fig. 3, II a). This curve does not, however, represent the first stage in the acquiring of writing. The first curves obtained are more or less characteristically drawing curves (Fig. 3, I.). Such curves are best seen where the child begins with printed letters rather than script (Fig. 3, I.c). In this case each stroke requires a definite and separate impulse, and this is well marked in the pressure curve. In the earliest script the curve seems merely irregular, but this is due to variations in the drawing unit with which the child is dealing, which may be a single stroke, a letter, or a group of letters. The second stage in learning to write is marked by what was formerly called the child type of pressure curve, a curve with a strikingly regular, flat top, which is still a drawing curve, though the child is now drawing the whole word. This curve passes gradually into the curve with rippled top of adult writing, the time when the transition can really be said to take place being about the age of ten or eleven (Fig. 3, III.). The transition seems to mean two things. In the first place the necessary co-ordinations are established to such an extent that the mechanism of writing works without attention to the individual strokes and forms which the hand is making. In the second place, and partly because of this, writing has ceased to be drawing and has become language, the rhythmical variations in point pressure corresponding to the rhythmical variations in grip pressure, and being analogous to a certain extent to the rhythm of speech. When this stage is reached the impulse under the direction of which writing takes place is distinctly a word impulse, and sometimes even a phrase or sentence impulse.

It has also been found that the writing of defectives fails to show this characteristic rhythm of adult writing, while drugs like alcohol tend to impair the rhythm and ultimately to break it down altogether, apparently because of their effect on co-ordination. It is also somewhat interesting to find that the pressure curve is almost as characteristic of an individual as his signature, and persists even in left-hand writing without previous practice. There is evidently a wide field for investigation in this direction, and perhaps we may yet see the development of a real science of graphology based upon such investigation.

\section{FLORA OF ADEN.1}

PROF. BLATTER has brought together an interesting account of the vegetation of the Aden peninsula, in which, after summarising the history of botanical exploration of this region from the earliest times, he gives data regarding physiography, climate, soils, tabulated lists of the plants, and brief notes on their distribution, origin, means of dispersal, etc. No references are made to work on plant ecology, but a comparison of the characters of the Aden vegetation with that of other arid regions, as investigated particularly by the Carnegie Institution botanical staff in North American and North African deserts, brings out some points of considerable ecological interest.

The first botanical description of Aden was given by Ibn Batuta in about 1330 , and it consisted of the brief statement that "there are neither seeds nor trees

1 "The Flora of Aden." By Ethelbert Blatter, Professor of Botany at St. Xavier's College, Bombay. Records of the Botanical Survey of India. Vol. vii, No. x. Calcutta, I9 4. Pp. ii 79 ; 5 plates; $x$ map. NO. 2372 , VOL. 95] nor water." Though Aden is not so entirely destitute of vegetation as this famous traveller supposed, the impression it produced upon much more recent botanical visitors was scarcely more favourable. Sir J. D. Hooker, in 1847 , described Aden as being "upon the whole the ugliest, blackest, most desolate, and most dislocated piece of land, of its size, that ever I set eyes upon, and I have seen a good many ugly places"; but he mentioned the comparatively fertile lower valleys, thickly studded with beautiful-flowered shrubs and small trees. Prof. Blatter's compilation is based largely upon the scattered reports and collections made by residents and visitors, and shows that Aden, despite the fact that it consists largely of "bare naked rocks which cannot find their equal in any part of the world as regards dryness, infernal heat, and barrenness,:" possesses an interesting and surprisingly varied vegetation.

The volcanic rocks forming the greater part of the Aden peninsula, which is about fifteen miles in circumference, are practically devoid of plant life; even lichens are scarce on the sun-baked and disintegrating rock-surfaces. These lofty and jagged rocks, rising in places to I $700 \mathrm{ft}$. altitude, are scored by steep gulleys and mostly run straight down to the shore, but here and there the lower slopes are gentle or almost flat, and in such places the clayey soil retains rain-wash, which elsewhere quickly runs off or percolates through the loose soil, and the vegetation in these parts is fairly rich. Apart from such habitats, the rigorous character of the conditions with which the Aden plants have to contend may be realised from the facts that there are no permanent streams or springs or marshes or ponds; the annual rainfall rarely exceeds six or seven inches in the wettest years; no rain may fall for two years at a time, and when it does fall it usually comes down in a torrent lasting for a day or two, changing the dry gulleys into turbulent streams which quickly dry up again.

The Aden flora consists of 2.50 species of flowering plants, including ten trees, fifty-eight shrubs, forty-six undershrubs, and ${ }_{13} 6$ herbs. The work of the Carnegie Institution botanists has shown that in the most arid regions of the earth, where the rainfall is extremely scanty, infrequent and irregular, what were formerly regarded as the typical desert-plants, namely, species with fleshy water-storing leaves and stems (cacti, etc.), are almost or entirely absent, and that the desert type par excellence is not succulent, but sclerophyllous. This term is applied to plants which do not store up water but contend with the extreme aridity of their environment by various adaptations for reducing water-loss to a minimum-reduced leaf surface, dense hair-covering, waxy cuticle, gummy epidermis, development of leaves or branches or both as spines, etc. From Prof. Blatter's iist such plants appear to be dominant in the vegetation of Aden; fleshy species are practically confined to the seacoast. A further point of interest is that about half of the herbaceous plants listed for Aden are shortlived annuals, which grow in the clayey soil of the flats and gentle slopes where water can be retained in the surface layers long enough for these plants to complete their brief life-cycle whenever rain comes. This, again, is a characteristic feature of the typical desert flora with clayey oases.

The records of the Botanical Survey of India contain so much that is, at any rate potentially, of general interest to students of plant ecology, that while the material they contain is welcome and useful, it is much to be hoped that the survey workers will make themselves acquainted with what has been and is being done on modern ecological lines, so that they may 
correlate their results with those obtained in other regions by the application of methods which alone can make a botanical survey what it is now generally expected to be-a correlated study of the plant communities and the plant habitats of the area surveyed.

F. C.

\section{ORNITHOLOGICAL NOTES.}

$A \mathrm{~T}$ the annual meeting of the Royal Society for the A Protection of Birds, held at the Middlesex Guildhall, on March Ix, when the Ranee of Sarawak presided, an optimistic tone prevailed in the first portion of the report for 19I4, as several of the schemes and objects. for which the Society had long been labouring were apparently on the point of realisation. Then came the war, when all these fair prospectsparticularly the expected passing of the Government Plumage Bill-were dissipated, to be renewed, it may be hoped, at the conclusion of the war. In other respects the work of the Society was, on the whole, satisfactory; but finance is a matter on which there is serious ground for anxiety, as a falling-off in subscriptions during the current year is almost inevitable.

The condor forms the subject of the first article in the March number of the Children's Museum News, where particular reference is made to the long period taken by these birds to attain the adult plumage. Hatched during the height of the southern summer, the young exchange their white nestling dress for a uniformly brown garb, which is not finally discarded until the seventh year, in February or the early part of March. Although able to fly when a year old, young condors do not leave their parents until the completion of their third year.

In the course of a wonderfully illustrated article on a breeding-colony of buff-backed herons, published in the March issue of Wild Life, Mr. B. Beetham directs attention to the small size of the nests of these birds, which alone renders it possible for so many to be crowded into a single bush. So heavily weighted, indeed, are some of the boughs that they hang almost vertically; and it is little short of marvellous how the eggs and young are retained in the shallow, cup-like nests, generally overhanging a lagoon, into which the hapless offspring may be precipitated by a gust of greater strength than usual. The nests are devoid of lining, and in some cases so flimsy in structure that the pale blue eggs are visible from below.

The nesting-habits of fulmar-petrels on a precipitous cliff in the Orkneys form the subject of an article by Mr. O. G. Pike in British Birds for March. The author arrived on the scene in the second week in July, when most of the young were hatched; but he was able to secure a couple of photographs of sitting birds, as well as one of a downy nestling. Each female lays but a single egg, and at a very early stage the young bird is capable of indulging in the distinctly petrel-trait of discharging a forceful jet of evil-smelling green oil from its mouth in the face of a real or supposed enemy.

To the Journal of the Straits Branch of the Royal Asiatic Society for December, I9r4, Mr. I. C. Moulton, curator of the Sarawak Museum, contributes a list of Bornean birds. In an appendix to Hugh Low's "Sarawak," published in 1848 , the number of species then recognised was fifty-nine; this was raised in I889 in a list drawn up by the late Mr. A. H. Everett to 536 (exclusive of thirty-four from Palawan), while in the present list the number is again augmented to 555; and this, too, despite the fact that several birds formerly regarded as distinct species have been relegated to the rank of local races.

NO. 2372 , VOL. 95]
According to the report in the January number of the Emu, the fourteenth annual session of the Royal Australasian Ornithologists" Union, held in Melbourne in November, I9I4, was a thorough success, a number of interesting excursions being taken and several papers read. In the same issue $\mathrm{Mr}$. A. J. Campbell directs attention to the apparent extermination of three beautifully coloured species of parrotsnamely, the scarlet-shouldered Psephotus pulcherrimus, the chestnut-shouldered grass-parrot (Euphema pulchella), and the night-parrot (Geopsittacus occidentalis), all of which were to be met with a few years ago in Queensland or the neighbouring districts. Their disappearance is attributed to domesticated cats run wild, aided by bush-fires and the spread of cultivation.

In the Zoologist for March, Prof. J. C. Patten describes an immature aquatic warbler picked up at Tuskar light-station, County Wexford, on August 9, I9I3. The paper is illustrated by a plate showing how the plumage of this species differs from that of the sedge-warbler at the same age. In the aquatic warbler the back is marked by streaks of black and buff, which are but slightly developed in the sedgewarbler; both webs of the middle pair of tail-feathers are also margined with buff, and all the tail-feathers are likewise longer, narrower, and more pointed than those of the sedge-warbler. The Tuskar bird is the second of its kind taken in Ireland; the number of specimens recorded from Great Britain (England) is seventeen.

R. L.

MOUNTAIN GEOLOGY.

$\mathrm{I}$ the Mémoires de la Société de Physique et d'His1 toire Naturelle de Genève (vol. xxxviii., pages 69-168). M. Louis Duparc and Mme. M. Tikanowitch continue their work on the Ural Chain by an account of its rocks to the east of the main watershed and in the upper basin of the rivers Kakwa and Wagran. This, the fourth of their contributions to the geology of that chain, is prefaced by a sketch of the physical features of the district, the illustrations to which show that it consists of huge hills rather than of rugged mountains. The rocks are partly sedimentary, arenaceous, or slaty argillaceous, with some quartzose crystalline schists; partly igneous. Of the latter a very complete petrographical study has been made, including chemical analyses of the principal types, several of which are very interesting. Among those of deep-seated origin are the following: quartz-bearing micaceous diorites (evidently allied to tonalites) and gabbrodiorites (in which probably the hornblende is secondary), olivine-gabbros, and massive dunites. Besides these and serpentines, are tilaite (a variety of eucrite) and pyroxenites. This association is interesting, for it often exists, more or less completely, in other regions, and suggests certain modes of magmatic differentiation. The dyke-rocks include hornblendic berbachites and various dioritic porphyrites, besides amphibolites, in some at least of which the hornblende appears to be secondary. The article ends with a description of the crystalline schists which, however, do not appear to be of any unusual interest. The memoir, illustrated by twelve photographic figures of the microscopic structure of the more interesting rocks, forms a most welcome addition to petrology, the more remarkable when we learn the difficulties with which the authors had to contend in their three visits to this region, in consequence of the sparse population, the want of roads, and the absence of maps.

In the next fascicule (pp. I69-98) M. Jules Favre describes the relation of the plant-life to the geology 